\title{
Differential Protein Expressions in Virus-Infected and Uninfected Trichomonas vaginalis
}

\author{
Ding He ${ }^{\dagger}$, Gong Pengtao ${ }^{\dagger}$ Yang Ju, Li Jianhua*, Li He, Zhang Guocai, Zhang Xichen* \\ College of Veterinary Medicine, Jilin University, Changchun 130062, P. R. China
}

\begin{abstract}
Protozoan viruses may influence the function and pathogenicity of the protozoa. Trichomonas vaginalis is a parasitic protozoan that could contain a double stranded RNA (dsRNA) virus, T. vaginalis virus (TV). However, there are few reports on the properties of the virus. To further determine variations in protein expression of $T$. vaginalis, we detected 2 strains of $T$. vaginalis; the virus-infected $\left(\mathrm{V}^{+}\right)$and uninfected $(\mathrm{V})$ isolates to examine differentially expressed proteins upon TV infection. Using a stable isotope N-terminal labeling strategy (iTRAQ) on soluble fractions to analyze proteomes, we identified 293 proteins, of which 50 were altered in $\mathrm{V}^{+}$compared with $\mathrm{V}$ isolates. The results showed that the expression of 29 proteins was increased, and 21 proteins decreased in $\mathrm{V}^{+}$isolates. These differentially expressed proteins can be classified into 4 categories: ribosomal proteins, metabolic enzymes, heat shock proteins, and putative uncharacterized proteins. Quantitative PCR was used to detect 4 metabolic processes proteins: glycogen phosphorylase, malate dehydrogenase, triosephosphate isomerase, and glucose-6-phosphate isomerase, which were differentially expressed in $\mathrm{V}^{+}$ and $\mathrm{V}$ isolates. Our findings suggest that mRNA levels of these genes were consistent with protein expression levels. This study was the first which analyzed protein expression variations upon TVV infection. These observations will provide a basis for future studies concerning the possible roles of these proteins in host-parasite interactions.
\end{abstract}

Key words: Trichomonas vaginalis, Trichomonas vaginalis virus, iTRAQ, quantitative PCR, protein expression

\section{INTRODUCTION}

Trichomoniasis is a curable non-viral sexually-transmitted disease (STD) caused by the flagellate protozoan Trichomonas vaginalis [1]. It has been recognized as a cause of vaginitis and cervicitis in women, and asymptomatic urethritis and prostatitis in men [2]. In recent years, T. vaginalis infection is related to preterm-deliveries and stillbirth [3], increased transmission of human immunodeficiency virus type 1 (HIV-1) [4], and cervical cancers [5]. In addition, as one of the deep-branching eukaryotes, T. vaginalis may serve as an excellent biological model for examining the evolution of eukaryotes [6].

T. vaginalis virus (TVV), belonging to the field of protozoan viruses, is a non-segmented double-stranded (ds) RNA virus infecting only T. vaginalis $[7,8]$. In protozoan viruses, Giardia lamblia virus (GLV) may arrest the growth of G. lamblia [9]; Leishmania virus possibly cause differences in virulence and pathol-

- Received 3 June 2016, revised 5 February 2017, accepted 22 February 2017.

*Corresponding author (Jianhuali7207@163.com; xczhang@j|u.edu.cn)

†These authors contributed equally to this study.

(c) 2017, Korean Society for Parasitology and Tropical Medicine

This is an Open Access article distributed under the terms of the Creative Commons Attribution Non-Commercial License (http://creativecommons.org/licenses/by-nc/4.0) which permits unrestricted non-commercial use, distribution, and reproduction in any medium, provided the original work is properly cited. ogy [10]; Cryptosporidium parrum virus (CPV) is a target for sensitive detection of C. parrum oocysts in water [11]. Yet, little is understood of the TVV, there is a study that TVV infection affects the phenotypic variation of a prominent immunogen, P270 protein [12]. To increase our understanding of the influence of virus-infected T. vaginalis $\left(\mathrm{V}^{+}\right)$, we analyzed the soluble proteins expressed by the virus-infected $\left(\mathrm{V}^{+}\right)$and uninfected (V) isolates by quantitative proteomic analysis.

The iTRAQ labeling method was used for comparative proteomic analysis in Plasmodium berghei [13] and Giardia lamblia [14]. In this study, we utilized the iTRAQ labeling method to identify differentially expressed proteins in 2 strains $\left(\mathrm{V}^{+}\right.$and $\mathrm{V}$. isolates) of T. vaginalis. These analyses will provide a useful basis for understanding the mechanisms involved in drug resistance, pathogenesis, and host-parasite interactions of T. vaginalis.

\section{MATERIALS AND METHODS}

\section{Parasite culture}

The $\mathrm{V}^{+}$(GenBank accession no. DQ528812) [15] and V isolates were isolated from clinical patients and cultured in our laboratory. The 2 stains were cultured in axenic TYM medium (pH 5.5) supplemented with $10 \%$ heat-inactivated calf serum 
at $37^{\circ} \mathrm{C}$, as previously described [16]. Cultured parasites were harvested during the logarithmic phase of growth, washed with PBS (PBS; pH 7.4) and stored at $-80^{\circ} \mathrm{C}$.

\section{Growth curve}

In order to observe the growth of $\mathrm{V}^{+}$and $\mathrm{V}$, an initial inoculum of $2 \times 10^{5}$ trophozoites per $\mathrm{ml}$ was grown in TYM medium (1.5 ml final volume), using 24 -well microtiter plates. Trophozoites were counted using a hemocytometer during $72 \mathrm{hr}$ (at 0 , $2,4,6,12,24,48$, and $72 \mathrm{hr}$ ). All tests were performed in triplicate. All data were analyzed with SPSS.

\section{Protein extraction and trypsin digestion}

The 2 strains of T. vaginalis, $1 \times 10^{8}$ trophozoites were homogenized with liquid nitrogen, and the cold-acetone method was used to extract the total protein. After adding 10\% trichloroacetic acid (TCA) in acetone to each sample, they were incubated at $-20^{\circ} \mathrm{C}$ for $2 \mathrm{hr}$ and then centrifuged $(20,000 \mathrm{~g}, 30 \mathrm{~min}$, $4^{\circ} \mathrm{C}$ ). The pellet was washed with acetone to reduce acidity and centrifuged again $\left(20,000 \mathrm{~g}, 30 \mathrm{~min}, 4^{\circ} \mathrm{C}\right)$. The wash step was repeated 3 times. The dried pellets were lysed with $1 \mathrm{ml}$ of protein extraction buffer ( $8 \mathrm{M}$ urea, $4 \%$ w/v CHAPS, $30 \mathrm{mM}$ HEPES, $1 \mathrm{mM}$ PMSF, $2 \mathrm{mM}$ EDTA, and $10 \mathrm{mM}$ DTT) and sonicated (2 sec sonication and $3 \mathrm{sec}$ incubation on ice, at $180 \mathrm{~W}$ for $5 \mathrm{~min}$ ). The resulting lysate was centrifuged $\left(20,000 \mathrm{~g}, 4^{\circ} \mathrm{C}, 30 \mathrm{~min}\right)$ to remove non-soluble impurities. Protein concentrations were measured using the 2-D Quant Kit (Amersham Biosciences, Piscataway, New Jersey, USA) according to the manufacturer's instructions and stored at $-80^{\circ} \mathrm{C}$ for future use.

\section{iTRAQ isobaric labeling}

For iTRAQ analysis, $100 \mu \mathrm{g}$ of each protein sample was denatured, and cysteines were blocked as described in the ITRAQ protocol (iTRAQ ${ }^{\circledast}$ Reagent-8Plex Multiplex Kit) (Applied Biosystems, Foster City, California, USA). The protein samples were then digested with $5 \mu \mathrm{g}$ of sequence-grade modified trypsin (Promega, Madison, Wisconsin, USA) at $37^{\circ} \mathrm{C}$ for $36 \mathrm{hr}$. Digested samples were dried in a centrifuge vacuum concentrator, and the protein pellets dissolved in $30 \mu \mathrm{l}$ of 50\% TEAB (Sigma, St. Louis, Missouri, USA) with $70 \mu$ of isopropanol, and labeled with iTRAQ reagents according to the manufacturer's protocol. The trypsin-digested samples were analyzed using a MALDI TOF/TOF mass spectrometer to ensure complete digestion. During labeling, iTRAQ-114 $\left(\mathrm{V}^{+}\right)$and iTRAQ-121 $(\mathrm{V})$ samples were tagged with 2 different iTRAQ reagents fol- lowing the manufacturer's instructions. The iTRAQ-labeled samples were then pooled and subjected to strong cation exchange (SCX) fractionation.

\section{SCX fractionation}

Labeled samples were fractionated using a high performance liquid chromatography (HPLC) system (Shimadzu, Kyoto, Japan) connected to an SCX column (Luna 5u column, $4.6 \mathrm{~mm}$ internal diameter (I.D.) $\times 250$ mm, $5 \mu \mathrm{m}, 100 \AA$ A Phenomenex, Torrence, California, USA). The labeled peptides were eluted using buffer $\mathrm{A}$ [10 $\mathrm{mM} \mathrm{KH}_{2} \mathrm{PO}_{4}$ in $25 \%$ acetonitrile ( $\mathrm{ACN}$ ), pH 3.0] and buffer B (2 M KCl, $10 \mathrm{mM} \mathrm{KH}_{2} \mathrm{PO}_{4}$ in $25 \% \mathrm{ACN}$, $\mathrm{pH}$ 3.0), and fractions were collected in 1.5-ml microcentrifuge tubes at a flow rate of $1 \mathrm{ml} / \mathrm{min}$ for $60 \mathrm{~min}$. A $60 \mathrm{~min}$ gradient was applied: 30 min with $100 \%$ buffer A; 1 min with $5 \%$ buffer B; 15 min with 30\% buffer B; 5 min with 50\% buffer B; and 5 min with $100 \%$ buffer B. All solutions used were freshly prepared and filtered through a $0.22-\mu \mathrm{m}$ pore membrane. Fraction collection commenced $31 \mathrm{~min}$ after injection, with fractions collected every $1 \mathrm{~min}$ to obtain a total of 38 fractions. For high salt concentration fractions, an additional step was used to remove the salt with a Strata-X 33u Polymeric Reversed Phase column (Phenomenex). Eluted fractions were dried in a vacuum concentrator, and each fraction was redissolved in $0.1 \%$ formic acid solution prior to reversed-phase nLC-tandem MS.

\section{Reversed-phase nanoliquid chromatography/tandem MS (LC-MS/MS)}

The equal amount of peptides in each fraction was injected into the nNano-liquid chromatography (Nano-LC) system. For analysis using MALDI-TOF/TOF, the SCX peptide fractions were pooled to reduce peptide complexity to yield 17 fractions. A $10-\mu l$ portion from each fraction was injected twice into the Proxeon Easy Nano-LC system (Thermo Scientific, West Palm Beach, Florida, USA). Peptides were separated on a C18 analytical reverse phase column at a flow rate of $300 \mathrm{nl} / \mathrm{min}$ with solvent (solution A, 5\% CAN and 0.1\% formic acid; solution $\mathrm{B}, 95 \% \mathrm{ACN}$ and $0.1 \%$ formic acid) for $120 \mathrm{~min}$. A linear LC gradient profile was used to elute peptides from the column, commencing with $5 \%$ solution B. After equilibration in 5\% solution $\mathrm{B}$, a multi-slope gradient started $10 \mathrm{~min}$ after the injection signal as follows: $45 \%$ solution B for $80 \mathrm{~min} ; 80 \%$ solution B for $15 \mathrm{~min}$; 5\% solution B for $15 \mathrm{~min}$; and then 5\% solution B. Fractions were analyzed using a hybrid quadrupole/ time-of-flight MS (Micro TOF-Q II; Bruker, Bremen, Germany) 
with nano electrospray ion source. Data were collected and analyzed using Data Analysis Software (Bruker). Nitrogen was used as the collision gas, and the MS/MS scans from 50-2,000 $\mathrm{m} / \mathrm{z}$ were recorded. The ionization tip voltage and interface temperature were set at $1,250 \mathrm{~V}$ and $150^{\circ} \mathrm{C}$, respectively.

\section{Data analysis}

All mass spectra data were collected using Bruker Daltonics micro TOF control, and processed and analyzed using Data Analysis Software. The Uniprot rat database was downloaded and integrated into the Mascot search engine (version 2.3.01) through the database maintenance unit. All parameters were set as follows: trypsin as the digestion enzyme; cysteine carbamidomethylation as fixed modification; iTRAQ 8Plex on $\mathrm{N}$ terminal residue; iTRAQ 8Plex on tyrosine (Y); iTRAQ 8Plex on lysine (K); glutamine as pyroglutamic acid; and oxidation on methionine $(\mathrm{M})$ as the variable modification. The tolerance settings for peptide identification in Mascot searches were 0.05 Da for MS and 0.05 Da for MS/MS. Mascot search results were normalized and quantified using Scaffold Software (version 3.0).

\section{Relative real-time quantitative PCR}

To examine the mRNA levels in the $\mathrm{V}^{+}$and $\mathrm{V}^{\text {}}$ strains, total RNA was extracted with a Protein and RNA Extraction $\mathrm{Kit}^{\mathrm{TM}}$ (TaKaRa, Shiga, Japan). Four differentially expressed genes encoding the following proteins were chosen: glycogen phosphorylase (AY050312.1), malate dehydrogenase (TVAG_204360), triosephosphate isomerase (TVAG_497370), and glucose-6-phosphate isomerase (AF425240.1). For relative real-time quantitative (RQ) PCR, glyceraldehyde 3-phosphate dehydrogenase (GAPDH) (GenBank no. L11394.1), a housekeeping gene of Trichomonas vaginalis was used as the internal standard. The primers used in quantitative real-time PCR were listed in Table 1. All

Table 1. Primers used in the quantitative real-time PCR

\begin{tabular}{lll}
\hline Primer name & & \multicolumn{1}{c}{ Primer sequence } \\
\hline $\begin{array}{c}\text { Glucose-6-phos- } \\
\text { phate isomerase }\end{array}$ & -F- & 5'-CAAGAGAATGGAAAACGGTGAA-3' \\
5'-CATAGCGAGAGTGTGAGCAAGAG-3' \\
$\begin{array}{c}\text { Glycogen phos- } \\
\text { phorylase }\end{array}$ & -F- & 5'-GCTGCGAGAACCTCACATCA-3' \\
Malate dehydroge- & -F- & 5'-AGGAGGGATGGGGAGAGGACA-3' \\
nase & -R- & 5'-GACGAGGAAGGCAACATCAAC-3' \\
Triosephosphate & -F- & 5'-CTATCGGCACAGGCAAGGT-3' \\
isomerase & -R- & 5'AGCACCACCAACGAGGAAG-3' \\
GAPDH & -F- & 5'-ATGGCTTCGCTCTCCGTGT-3' \\
& -R- & 5'-GGCGTTGACTTCCTCCTTGT-3' \\
\hline
\end{tabular}

tests were performed in triplicate in the same run. Data analysis was carried out using ABIprism 7000 SDS software (version 1.2.3). The results were expressed as the ratio between the 4 above-mentioned proteins mRNA and GAPDH mRNA in the samples.

\section{RESULTS}

\section{Growth curve}

To observe the growth of T. vaginalis $\mathrm{V}^{+}$and $\mathrm{V}$ strains, an initial inoculum of $2 \times 10^{5}$ per ml trophozoites were cultured in 24-well microtiter plates with $1.5 \mathrm{ml}$ TYM medium, counting of parasites using a hemocytometer during $72 \mathrm{hr}$ (at 0, 2, 4, 6, $12,24,48$, and $72 \mathrm{hr}$ ). Trophozoite growth reached the highest density in $24 \mathrm{hr}$ and decreasing after $72 \mathrm{hr}$ of incubation, and no significant difference was found between the 2 strains (Fig. 1).

\section{Identification of proteins by ITRAQ}

With respect to cultivation of the $\mathrm{V}^{+}$and $\mathrm{V}^{+}$isolates, we did not observe significant differences using microscopy. To identify the variation in levels of expressed proteins between isolates, proteins were labeled with iTRAQ reagents. This analysis revealed that 293 proteins were expressed, with at least 2 peptides identified. The expression value of the proteins for the $\mathrm{V}$ isolate was considered to be zero, while $\mathrm{V}^{+}$isolate proteins expressed at levels 1-fold higher or lower were considered to be differentially expressed. Of 293 proteins, 50 were differentially expressed, with 21 down-regulated and the remainder up-regulated upon TVV infection.

Among these proteins, 4 were putative and previously uncharacterized. One of these uncharacterized proteins was found to be up-regulated upon TVV infection, and the remaining 3

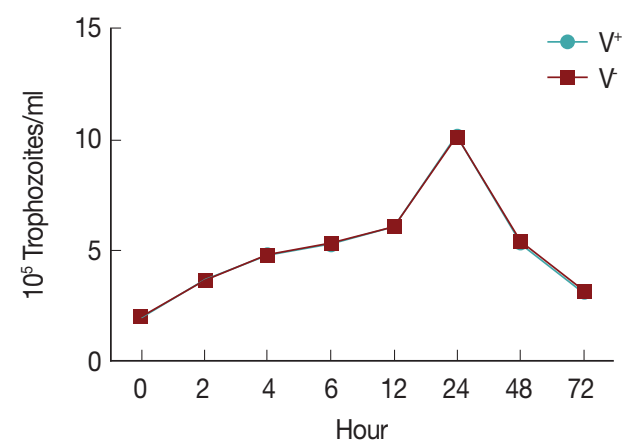

Fig. 1. The growth curve of $T$. vaginalis. 


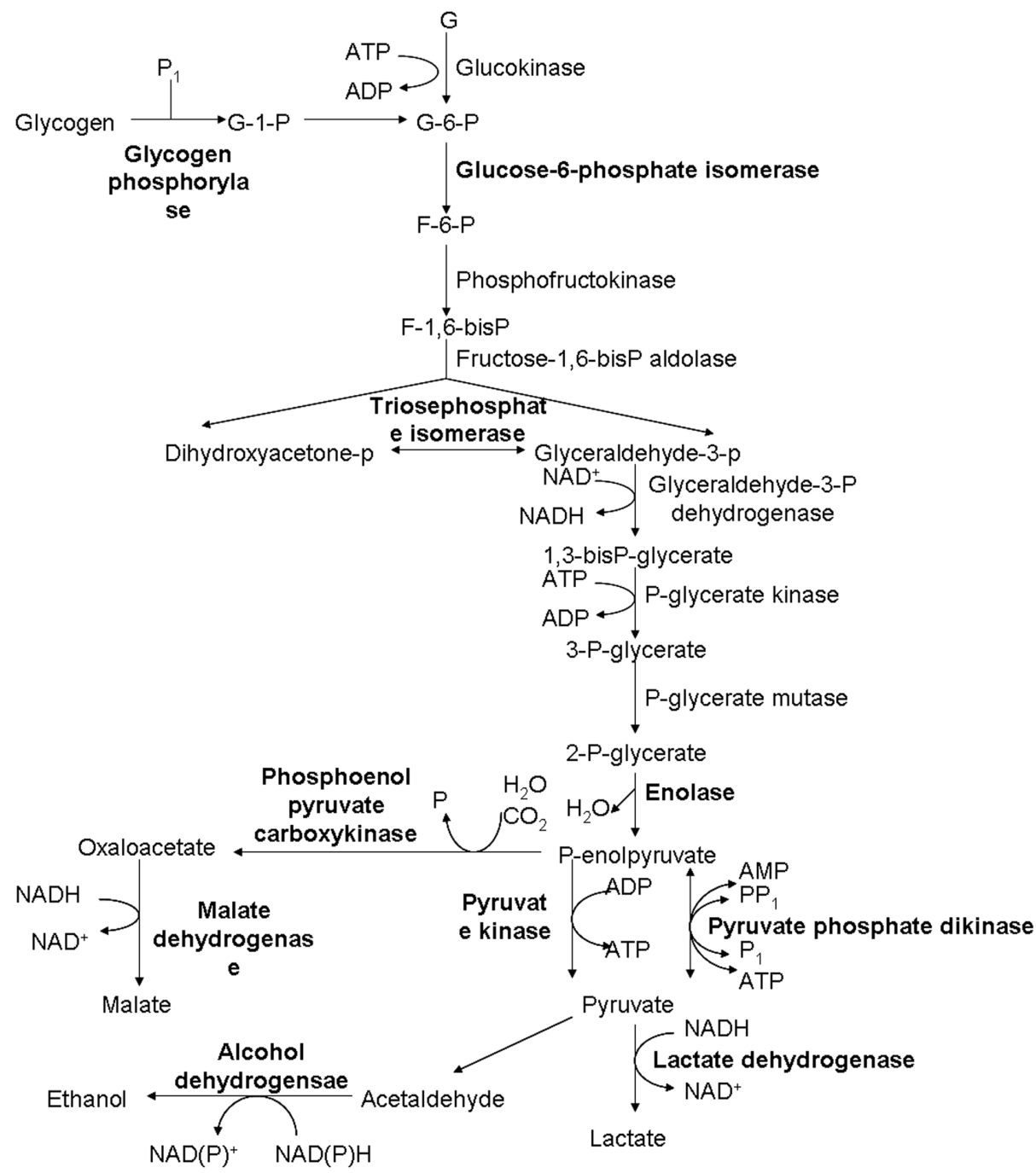

Fig. 2. Differential expression of enzymes involved in glycolytic pathways between $\mathrm{V}^{+}$and $\mathrm{V}$ isolates of $T$. vaginalis. The highlight parts represent the changed expression proteins.

were down-regulated. Total 9 ribosomal proteins showed increased expression levels in $\mathrm{V}^{+}$isolates. The expression of 3 heat shock proteins was decreased. Proteins associated with metabolism, such as elongation factor-1 $\alpha$, histidyl-tRNA synthetases, and translation elongation factor- $1 \beta$, were up-regulated. Histones $\mathrm{H} 2 \mathrm{~B}$ and $\mathrm{H} 4$ were up-regulated, while actin and fimbrin were downregulated. Twenty metabolic enzymes, particularly in carbohydrate metabolism (Fig. 2), and other proteins were also differentially expressed. All the results are listed in Table 2.

\section{Relative real-time quantitative PCR}

Total RNAs were extracted with protein and RNA extraction $\mathrm{Kit}^{\mathrm{TM}}$ (Takara) from the virus-infected $\left(\mathrm{V}^{+}\right)$and uninfected $(\mathrm{V})$ isolates (Fig. 3). To elucidate the levels of mRNA expression in the $\mathrm{V}^{+}$and $\mathrm{V}^{-}$isolates, the relative quantities between 4 of glycolytic pathway proteins and GAPDH mRNA were assayed by relative real-time quantitative PCR and expressed as the ratio between the 4 above-mentioned proteins and GAPDH mRNA (Fig. 4).

The mRNA expression levels were significantly different between $\mathrm{V}^{+}$and $\mathrm{V}$ isolates. The level of glycogen phosphorylase mRNA and malate dehydrogenase mRNA expression were decreased $39 \%$ and $11 \%$ (the ratios were 1.31 and 1.07 ), respectively, triosephosphate isomerase and glucose-6-phosphate isomerase were increased $67 \%$ and $82 \%$ (the ratios were 1.59 and 1.77), respectively, in the $\mathrm{V}^{+} T$. vaginalis isolate relative to the $\mathrm{V}^{\mathrm{V}}$ T. vaginalis isolate. Hence, upon TVV infection, some of the proteins and their mRNA expressions were changed. 
Table 2. Differential protein expression between $\mathrm{V}$ and $\mathrm{V}^{+}$isolates of Trichomonas vaginalis

\begin{tabular}{|c|c|c|c|c|c|}
\hline & Protein name & $\begin{array}{l}\text { \#of unique } \\
\text { peptide }\end{array}$ & $\mathrm{V}$ & $\mathrm{V}^{+}$ & Value \\
\hline \multirow{4}{*}{$\begin{array}{l}\text { Putative uncharac- } \\
\text { terized proteins }\end{array}$} & Putative uncharacterized protein (TVAG_455090) & 7 & 0 & 0.95 & 1.93 \\
\hline & Putative uncharacterized protein (TVAG_047990) & 3 & 0 & -0.19 & 1.14 \\
\hline & Putative uncharacterized protein (TVAG_420260) & 12 & 0 & -0.18 & 1.13 \\
\hline & Putative uncharacterized protein (TVAG_336940) & 3 & 0 & -0.22 & 1.17 \\
\hline \multirow[t]{9}{*}{ Ribosomal protein } & Ribosomal protein L14 (TVAG_026460) & 5 & 0 & 0.44 & 1.36 \\
\hline & 60S ribosomal protein L30 (TVAG_192910) & 3 & 0 & 0.42 & 1.34 \\
\hline & Ribosomal protein S13p/S18e (TVAG_020480) & 6 & 0 & 0.01 & 1.01 \\
\hline & Ribosomal protein (TVAG_476810) & 7 & 0 & 0.56 & 1.47 \\
\hline & 40S ribosomal protein S8 (TVAG_066030) & 8 & 0 & 0.07 & 1.05 \\
\hline & Ribosomal protein L10 (TVAG_051160) & 10 & 0 & 0.44 & 1.36 \\
\hline & 40S ribosomal protein S7 (TVAG_199100) & 2 & 0 & 0.06 & 1.04 \\
\hline & Ribosomal protein S3 (TVAG_106800) & 5 & 0 & 0.26 & 1.2 \\
\hline & 40S ribosomal protein S7 (TVAG_198680) & 2 & 0 & -0.16 & 1.12 \\
\hline \multirow[t]{3}{*}{ Heat shock protein } & Endoplasmic reticulum heat shock protein 70 (TVAG_092490) & 4 & 0 & -0.04 & 1.03 \\
\hline & Heat shock protein (TVAG_153560) & 9 & 0 & -0.09 & 1.06 \\
\hline & Cytoplasmic heat shock protein 70 (TVAG_044510) & 26 & 0 & -0.15 & 1.11 \\
\hline \multirow{4}{*}{$\begin{array}{l}\text { Protein synthesis } \\
\text { metabolism }\end{array}$} & Lysyl-tRNA synthetase (TVAG_152430) & 3 & 0 & -0.11 & 1.08 \\
\hline & Histidyl-tRNA synthetase family protein (TVAG_342610) & 2 & 0 & 0.37 & 1.29 \\
\hline & Elongation factor 1-alpha (TVAG_067400) & 17 & 0 & 0.04 & 1.03 \\
\hline & Translation elongation factor 1 beta (TVAG_453990) & 2 & 0 & 0.46 & 1.38 \\
\hline \multirow[t]{2}{*}{ Histone } & Histone H2B (TVAG_026390) & 2 & 0 & 0.28 & 1.21 \\
\hline & Histone H4 (TVAG_014920) & 5 & 0 & 0.36 & 1.28 \\
\hline \multirow[t]{2}{*}{ Cytoskeletal proteins } & Fimbrin (TVAG_351310) & 4 & 0 & -0.59 & 1.51 \\
\hline & Actin (U63122.1) & 6 & 0 & -0.21 & 1.16 \\
\hline \multirow{20}{*}{$\begin{array}{l}\text { Metabolic processes } \\
\text { protein }\end{array}$} & Glucose-6-phosphate isomerase (AF425240.1) & 3 & 0 & 0.46 & 1.38 \\
\hline & Cytosolic malate dehydrogenase (U38692.1) & 8 & 0 & 0.14 & 1.1 \\
\hline & Triosephosphate isomerase (TVAG_497370) & 2 & 0 & 0.77 & 1.71 \\
\hline & Malic enzyme (AF545470.1) & 2 & 0 & 0.02 & 1.01 \\
\hline & Alcohol dehydrogenase 1 (TVAG_228780) & 5 & 0 & 0.27 & 1.21 \\
\hline & Alcohol dehydrogensae (TVAG_422780) & 6 & 0 & 0.13 & 1.09 \\
\hline & Pyrophosphate-dependent fructose 6-phosphate 1-phosphotransferase (AF044973.1) & 4 & 0 & 0.36 & 1.28 \\
\hline & Hydrogenosomal oxygen reductase (TVAG_036010) & 2 & 0 & 0.28 & 1.21 \\
\hline & Pyruvate, phosphate dikinase family protein (TVAG_073860) & 7 & 0 & 0.08 & 1.06 \\
\hline & Thioredoxin reductase (TVAG 474980) & 3 & 0 & 0.31 & 1.24 \\
\hline & Clan MH, family M20, peptidase T-like metallopeptidase (TVAG_437930) & 11 & 0 & 0.32 & 1.25 \\
\hline & V-type ATPase 116 kDa subunit family protein (TVAG_075320) & 2 & 0 & -0.31 & 1.24 \\
\hline & Phosphoenol pyruvate carboxykinase (TVAG_310250) & 6 & 0 & -0.11 & 1.08 \\
\hline & L-lactate dehydrogenase, putative (TVAG_171090) & 3 & 0 & -0.48 & 1.39 \\
\hline & Malate dehydrogenase (TVAG_204360) & 5 & 0 & -0.71 & 1.64 \\
\hline & Glycogen phosphorylase (AY050312.1) & & 0 & -0.5 & 1.41 \\
\hline & Enolase (TVAG_464170) & 11 & 0 & -0.45 & 1.37 \\
\hline & 4-alpha-glucanotransferase family protein (TVAG_157940) & 7 & 0 & -0.02 & 1.01 \\
\hline & Clan MG, familly M24, aminopeptidase P-like metallopeptidase (TVAG_224980) & 4 & 0 & -0.59 & 1.51 \\
\hline & Adenosinetriphosphatase (TVAG_453110) & 9 & 0 & -0.3 & 1.23 \\
\hline \multirow{6}{*}{$\begin{array}{l}\text { Other predicted } \\
\text { function protein }\end{array}$} & ABC transporter family protein (TVAG_461020) & 2 & 0 & 2.15 & 4.45 \\
\hline & 14-3-3 protein (TVAG_462940) & 7 & 0 & 0.03 & 1.02 \\
\hline & Adhesin protein AP33-1 (U87096.1) & 2 & 0 & 1.01 & 2.02 \\
\hline & Adhesin protein AP51-3 (TVAG_183500) & 10 & 0 & 0.55 & 1.46 \\
\hline & Ras-related protein Rab11C (TVAG_169740) & 2 & 0 & 0.5 & 1.41 \\
\hline & DJ-1 family protein (TVAG_420420) & 9 & 0 & -0.16 & 1.12 \\
\hline
\end{tabular}

$\mathrm{V}$ or $\mathrm{V}^{+}$indicates uninfected or $\mathrm{TW}$-infected strains of $\mathrm{TV}$, respectively.

The $\mathrm{V}$ and $\mathrm{V}^{+}$reporter is the log2 value of the fold difference.

The values are indicated as the fold difference between $\mathrm{V}$ and $\mathrm{V}^{+}$. 


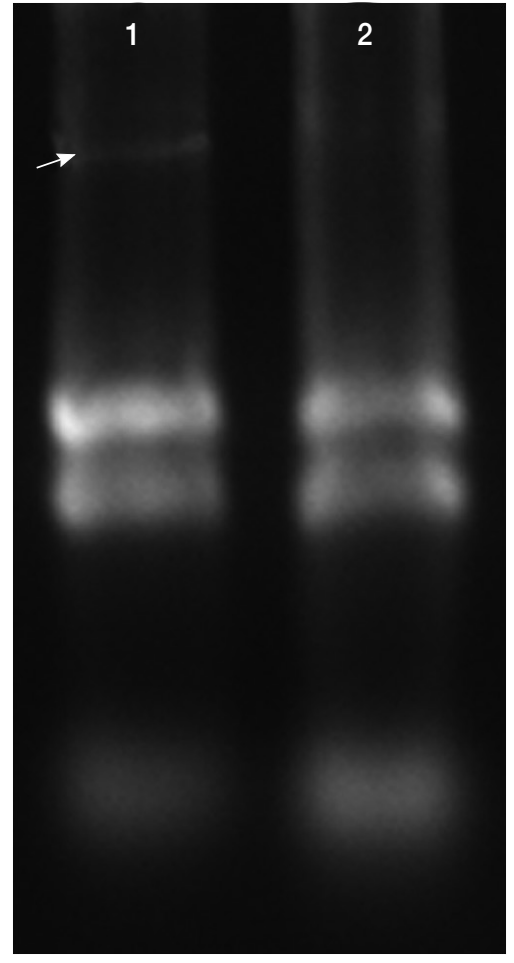

Fig. 3. Total RNAs extracted in T. vaginalis. Total RNAs were extracted from the virus-infected $\left(\mathrm{V}^{+}\right)$and uninfected $(\mathrm{V})$ isolates, virus-infected isolate showed obvious viral band (arrow) compared with virus-uninfected isolate (lane 2).

\section{DISCUSSION}

Numerous protozoa could be infected by virus, which may be involved in the function and pathogenicity of these protozoa [9-11]. More than $50 \%$ of T. vaginalis strains are infected with TVV, yet little is understood on the viruses which infect these protozoa. Previous studies have indicated that virus infection could influence surface expression of phenotypic characteristics of the host cells and alter the virulence of trichomonads [12,17-19]. To the best of our knowledge, this is the first proteomics investigation of T. vaginalis. We identified $293 \mathrm{~T}$. vaginalis proteins, 50 of which were differentially expression between $\mathrm{V}^{+}$and $\mathrm{V}$ isolates. These proteins were divided into 4 categories; ribosomal proteins, metabolic enzymes, heat shock proteins, and putative uncharacterized proteins. These proteins were involved in different aspects of T. vaginalis infection.

The mechanisms of clinical metronidazole resistance in $T$. vaginalis are currently unclear, despite previous studies which showed differential expression of various proteins, including down-regulation of flavin reductase, alcohol dehydrogenase-1, hydrogenosomal oxygen reductase, and thioredoxin reductase

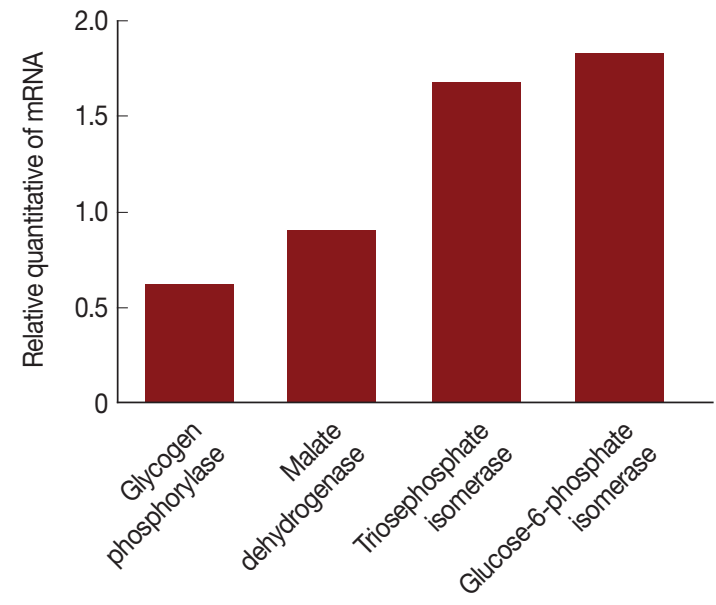

Fig. 4. Comparison of mRNA levels between uninfected and TWinfected T. vaginalis strains. Glycogen phosphorylase and malate dehydrogenase mRNA expressions were significantly lower in the $\mathrm{V}^{+}$isolate relative to the $\mathrm{V}$ isolate. Triosephosphate isomerase and glucose-6-phosphate isomerase mRNA expressions were significantly increased in the $\mathrm{V}^{+}$isolate relative to the $\mathrm{V}^{-}$isolate.

[20], and up-regulation of lactate dehydrogenase [21]. In this study, by comparison with an uninfected T. vaginalis strain, TVVinfected T. vaginalis $\left(\mathrm{V}^{+}\right)$showed significant down-regulation of alcohol dehydrogenase-1, hydrogenosomal oxygen reductase, and thioredoxin reductase. The expression of L-lactate dehydrogenase in $\mathrm{V}$ isolates was up-regulated. These data were consistent with previous studies and might explain the reason why uninfected T. vaginalis strain can be drug-resistant [22]. Conversely, T. vaginalis strains infected with TVV are more likely to be sensitive to metronidazole. Additionally, the ABC transporter family protein, containing a Fe-S binding site [23], plays a key role in multidrug resistance of cancer and yeast cells. It was likely involved in drug resistance of various pathogenic protozoa [24]. However, it was shown to be up-regulated in $\mathrm{V}^{+}$ isolate. Thus, to clarify the association of TVV with the drug resistance in T. vaginalis, further studies are required.

About pathogenicity, we confirmed the up-regulation of adhesin proteins, AP33-1 and AP51-3 in virus-infected T. vaginalis. These proteins bind to the surface of vaginal epithelial cells and are implicated in cell adhesion and host cell invasion [2527]. It was previously suggested that virus infection might increase the pathogenicity of $T$. vaginalis $[17,18]$. In a previous study, virus infection regulated the surface immunogen P270, which influenced the pathogenicity of T. vaginalis. However, using iTRAQ reagents, we could not detect P270 in either $\mathrm{V}^{+}$or $\mathrm{V}$ isolates. This was likely due to its low abundance.

Despite the frequent occurrence of virus infections in T. vagi- 
nalis, the molecular mechanisms of infection remain largely unknown. We identified 50 proteins in T. vaginalis that were affected by TVV infection. These proteins were associated with various functions, including gene transcription and expression (e.g., ABC EI protein) [23], RNA packaging of HIV-1 genomic RNA into nascent virions and association with RNA polymerase of vesicular stomatitis virus (e.g., elongation factor 1- $\alpha(E F 1 \alpha)$ [28,29], and monoubiquitination of histone H2B [30]. All of these proteins were found to be up-regulated in the $\mathrm{V}^{+}$isolate compared with the $\mathrm{V}$ isolate. However, further studies are needed to show whether these proteins participate in the virus life cycle.

Heat shock proteins (Hsps) are important molecular chaperones that participate in protein translation, folding, and trafficking [31]. Some reports have found that Hsp70 is induced by virus infection in animal and plant cells [32]. Using the iTRAQ method, we observed that 3 Hsps were down-regulated in the $\mathrm{V}^{+}$isolate. Although the reason for this was unclear, it is probably an indicator that TVV protein translation requires the presence of the aforementioned Hsps, especially Hsp70.

According to data analysis, there were 10 differential expression enzymes in glycolytic pathways; therefore, we applied qPCR assays to analyze the expression of genes encoding glycogen phosphorylase, malate dehydrogenase, triosephosphate isomerase, and glucose-6-phosphate isomerase to detect variation of mRNA levels. Our findings indicate that mRNA production was altered; therefore, virus infection likely influenced the transcription level of $T$. vaginalis genes.

In summary, we have conducted the first major proteomics investigation of T. vaginalis. We screened the expression levels of proteins in uninfected and TV-infected T. vaginalis strains, and found 50 differentially expressed proteins. Our results could facilitate further studies for the mechanisms of drug resistance and the virulence of TVV.

\section{ACKNOWLEDGMENTS}

This work was supported by the National Natural Science Foundation of China (no. 30300260). We declare that the experiments comply with the current laws of China where they were performed.

\section{CONFLICT OF INTEREST}

We have no conflict of interest related to this work.

\section{REFERENCES}

1. Johnston VJ, Mabey DC. Global epidemiology and control of Trichomonas vaginalis. Curr Opin Infect Dis 2008; 21: 56-64.

2. Mielczarek E, Blaszkowska J. Trichomonas vaginalis: pathogenicity and potential role in human reproductive failure. Infection 2016; 44: 447-458.

3. Centers for Disease Control and Prevention, Workowski KA, Berman SM. Sexually transmitted diseases treatment guidelines, 2006. MMWR Recomm Rep 2006; 55: 1-94.

4. McClelland RS, Sangare L, Hassan WM, Lavreys L, Mandaliya K, Kiarie J, Ndinya-Achola J, Jaoko W, Baeten JM. Infection with Trichomonas vaginalis increases the risk of HIV-1 acquisition. J Infect Dis 2007; 195: 698-702.

5. ViikkiM, Pukkala E, Nieminen P, Hakama M. Gynaecological infections as risk determinants of subsequent cervical neoplasia. Acta Oncol 2000; 39: 71-75.

6. Embley TM, Martin W. Eukaryotic evolution, changes and challenges. Nature 2006; 440: 623-630.

7. Wang A, Wang CC, Alderete JF. Trichomonas vaginalis phenotypic variation occurs only among trichomonads infected with the double-stranded RNA virus. J Exp Med 1987; 166: 142-150.

8. Wang AL, Wang CC. The double-stranded RNA in Trichomonas vaginalis may originate from virus-like particles. Proc Natl Acad Sci U S A 1986; 83: 7956-7960.

9. Miller RL, Wang AL, Wang CC. Purification and characterization of the Giardia lamblia double-stranded RNA virus. Mol Biochem Parasitol 1988; 28: 189-195.

10. Stuart KD, Weeks R, Guilbride L, Myler PJ. Molecular organization of Leishmania RNA virus 1. Proc Natl Acad Sci U S A 1992; 89: 8596-8600.

11. Kniel KE, Higgins JA, Trout JM, Fayer R, Jenkins MC. Characterization and potential use of a Cryptosporidium parvum virus (CPV) antigen for detecting C. parrum oocysts. J Microbiol Methods 2004; 58: 189-195.

12. Khoshnan A, Alderete JF. Trichomonas vaginalis with a double-stranded RNA virus has upregulated levels of phenotypically variable immunogen mRNA. J Virol 1994; 68: 4035-4038.

13. Choumet V, Carmi-Leroy A, Laurent $C$, Lenormand $P$, Rousselle JC, Namane A, Roth C, Brey PT. The salivary glands and saliva of Anopheles gambiae as an essential step in the Plasmodium life cycle: a global proteomic study. Proteomics 2007; 7: 3384-3394.

14. Lingdan L, Pengtao G, Wenchao L, Jianhua L, Ju Y, Chengwu L, He L, Guocai Z, Wenzhi R, Yujiang C, Xichen Z. Differential dissolved protein expression throughout the life cycle of Giardia lamblia. Exp Parasitol 2012; 132: 465-469.

15. Li W, Ding H, Zhang X, Cao L, Li J, Gong P, Li H, Zhang G, Li S, Zhang $\mathrm{X}$. The viral RNA-based transfection of enhanced green fluorescent protein (EGFP) in the parasitic protozoan Trichomonas vaginalis. Parasitol Res 2012; 110: 1305-1310.

16. Diamond LS. The establishment of various trichomonads of animals and man in axenic cultures. J Parasitol 1957; 43: 488-490.

17. Alderete JF. Trichomonas vaginalis NYH286 phenotypic variation 
may be coordinated for a repertoire of trichomonad surface immunogens. Infect Immun 1987; 55: 1957-1962.

18. Alderete JF, Deměs P, Gombosová A, Valent M, Yánoska A, Fabusová H, Kasmala L, Garza GE, Metcalfe EC. Phenotype and protein-epitope phenotypic variation among fresh isolates of Trichomonas vaginalis. Infect Immun 1987; 55: 1037-1041.

19. Alderete JF, Kasmala L, Metcalfe E, Garza GE. Phenotypic variation and diversity among Trichomonas vaginalis isolates and correlation of phenotype with trichomonal virulence determinants. Infect Immun 1986; 53: 285-293.

20. Leitsch D, Drinic M, Kolarich D, Duchêne M. Down-regulation of flavin reductase and alcohol dehydrogenase-1 (ADH1) in metronidazole-resistant isolates of Trichomonas vaginalis. Mol Biochem Parasitol 2012; 183: 177-183.

21. Leitsch D, Kolarich D, Duchêne M. The flavin inhibitor diphenyleneiodonium renders Trichomonas vaginalis resistant to metronidazole, inhibits thioredoxin reductase and flavin reductase, and shuts off hydrogenosomal enzymatic pathways. Mol Biochem Parasitol 2010; 171: 17-24.

22. Snipes LJ, Gamard PM, Narcisi EM, Beard CB, Lehmann T, Secor WE. Molecular epidemiology of metronidazole resistance in a population of Trichomonas vaginalis clinical isolates. J Clin Microbiol 2000; 38: 3004-3009.

23 Chen ZQ, Dong J, Ishimura A, Daar I, Hinnebusch AG, Dean M. The essential vertebrate $\mathrm{ABCE} 1$ protein interacts with eukaryotic initiation factors. J Biol Chem 2006; 281: 7452-7457.

24. Mäser P, Kaminsky R. Identification of three ABC transporter genes in Trypanosoma brucei spp. Parasitol Res 1998; 84: 106-111.
25. Engbring JA, Alderete JF. Three genes encode distinct AP33 proteins involved in Trichomonas vaginalis cytoadherence. Mol Microbiol 1998; 28: 305-313.

26. Engbringtand JA, Alderete JF. Characterizationof Trichomonas vaginalis AP33 adhesin and cell surface interactive domains. Microbiology 1998; 144: 3011-3018.

27. Garcia AF, Alderete JF. Characterization of the Trichomonas vaginalis surface-associated AP65 and binding domain interacting with trichomonads and host cells. BMC Microbiol 2007; 7: 116.

28. Cimarelli A, Luban J. Translation elongation factor 1-alpha interacts specifically with the human immunodeficiency virus type 1 Gag polyprotein. JVirol 1999; 73: 5388-5401.

29. Das T, Mathur M, Gupta AK, Janssen GM, Banerjee AK. RNA polymerase of vesicular stomatitis virus specifically associates with translation elongation factor- $1 \alpha \beta \gamma$ for its activity. Proc Natl Acad Sci USA 1998; 95: 1449-1454.

30. Fujiki R, Hashiba W, Sekine H, Yokoyama A, Chikanishi T, Ito S, Imai Y, Kim J, He HH, Igarashi K, Kanno J, Ohtake F, Kitagawa H, Roeder RG, Brown M, Kato S. GlcNAcylation of histone H2B facilitates its monoubiquitination. Nature 2011; 480: 557-560.

31. Hartl FU, Hayer-Hartl M. Molecular chaperones in the cytosol: from nascent chain to folded protein. Science 2002; 295: 18521858.

32. Aparicio F, Thomas CL, Lederer C, Niu Y, Wang D, Maule AJ. Virus induction of heat shock protein 70 reflects a general response to protein accumulation in the plant cytosol. Plant Physiol 2005; 138: 529-536. 